\title{
Evaluation of the increase in orthodontic treatment demand in adults
}

\section{Avaliação do crescimento da incidência de tratamento ortodôntico em pacientes adultos}

\author{
Eduardo César WERNECK \\ Coordinator - Curso de especialização do I.E.P.C. - Cruzeiro - SP - Brazil.
}

Fernanda Silva MATTOS

Orthodontist - I.E.P.C. - Cruzeiro - SP - Brazil.

\section{Márcio Garcia da SILVA}

Orthodontist - CTA - São José dos Campos - SP - Brazil.

\section{Renata Falchete do PRADO}

PhD in Pathology -- Faculdade de Odontologia de São José dos Campos - UNESP - Univ Estadual Paulista - São José dos campos - SP - Brazil.

\section{Adriano Marotta ARAÚJO}

Assistant Professor - Department of Social Science and Pediatric Dentistry- UNESP - Univ Estadual Paulista - São José dos Campos - SP - Brazil.

\begin{abstract}
ABSTR ACT
Preventive measures in Dentistry and the modernization of the orthodontics appliances led adult patients to seek orthodontic treatment to improve their appearance and social acceptance, as well as function and oral health. Adult patients present some peculiarities such as periodontal disease and tooth loss which complicates the mechanotherapy, requiring a multidisciplinary team and a more complex mechanics. Thus, the aim of this study was to verify the proportion of young and adult patients who started orthodontic treatment in the period from 2000 to 2010, as well as the total percentage, and to correlate male and female values. The sample of 3,272 patients was divided into three groups according to the age: up to 20 (group 1), from 20 to 40 (group 2) and above 40 years-old (group 3), according to gender. It was found that most patients were young (group 1: 71.85\%). However, the number of adults from 20 to 40 years-old represents a considerable share of $26.52 \%$. Above 40 years-old, $1.61 \%$ patients sought for orthodontic treatment. If we consider the patient in the age-range above 20 years-old as adult, there was a considerable increasing in the values from $12.14 \%$, in 2000 to $27.81 \%$ in 2010, especially in females (31.26\%), mainly in groups 2 and 3, showing that dental aesthetics is an important factor for the individual social insertion.
\end{abstract}

\section{K EYWORDS}

Corrective orthodontics; dental esthetics; data collection.

\section{INTRODUCT ION}

The aesthetic perception of malocclusion is an important factor for adult patients seeking for orthodontic treatment [1]. These patients reported strong motivation and defined capacity in the need of treatment [2], because for them, small differences in dental aesthetic can affect self-perception significantly [3]. However, there are evidences that this issue can be perceived in 
different forms by different ethnic groups [4$6]$. Depending on the region, some social class will search for this factor with greater intensity, mainly because of costs rather than need or demand [7].

It can also be highlighted that orofacial region is an area of significantly concern and great value in interpersonal relationship, and also the main source of vocal, physical and emotional communication. As consequence, patients seeking orthodontic treatment are more concerned about improving their appearance and social acceptance than improving their oral healthy and function [8]. In absence of appropriate dental aesthetic, adult patients can choose three paths: avoid showing teeth, minimize the importance of appearance or search for orthodontic treatment [9].

Currently, there is a tendency towards growth in the number of adults seeking the correction of teeth position [10], resulting in a considerable increasing in their proportion in many dental offices, which in some cases, become more than half of patients in treatment [11].

Researches in the early of the 90's showed that the percentage of adult patients in orthodontic clinics was around $30 \%$ [12]. These values have increased due to factors such as the use of preventive measures in Dentistry, allowing reach adulthood with the presence of a higher number of teeth [12-14], the greatest access to information that enables adults to recognize orthodontics as a viable resource to improve their appearance and the modernization of orthodontic appliances that have become more aesthetic $[15,16]$.

Although live longer is a positive factor [10], extension of lifetime requires an extensive organization and special cares with the treatment of these patients $[17,18]$. Adult patients (whose growth has already finished) have some particularities as periodontal diseases and tooth loss [19], making the mechanotherapy difficult, usually with a multidisciplinary approach and a more complex treatment planning and mechanics [20-23].

Normally, they have midline diastemas or generalized spaces, excessive labial inclination and extrusion of upper incisors, rotation and inclination of premolars and molars with collapse of posterior occlusion [24]. Thus, it is not often possible to achieve the ideal occlusion relationship of Class I (mainly in the age-range of 40 years-old) even though these patients have a high-degree requirement in relation to the results of the treatment [25].

The most prevalent malocclusions are crowding, increased overjet and crossbite [26], with almost two thirds of the orthodontically treated patients reporting an improve in dental appearance, with females being more critical than males [27], although the malocclusion impact on the quality of young adults life in both genders are similar [28].

Finally, the prevalence of signs and symptoms of temporomandibular disorders (TMD) and its association with joint noise, articular hypermobility, occlusal interferences and bruxism occurs around $42 \%$ in adult patients, consequently it is recommended that these cases be followed-up for the appearance of TMD symptoms [29].

Within this context, the aim of this study is to verify comparatively the proportion of adult and young patients who had began orthodontic treatment in the period from 2000 to 2010 , and to correlate male and female values, as well as the total percentage of patients who had started treatment in this period.

\section{Material and Methods}

Data from patients treated in the Institute of Teaching and Research of Cruzeiro were used. A sample of 3,272 patients who had started orthodontic treatment in the period from 2000 to 2010 was used and divided into three groups according to age: group 1 (up to 20 years-old), group 2 (20 to 40 years-old) and group 3 (above 40 years-old). The groups were also divided according to males and females. The results were tabulated and submitted to descriptive statistics.

\section{Results}

Data were tabulated (tables 1 and 2), submitted to descriptive statistical analysis and graphics were established for a better visualization of the results. It was verified an increasing of the number of adult patients who started orthodontic treatment (table 1, graphic 1), mainly for groups 2 and 3 , with greater number of females, as it can be observed in graphics 2, 3 and 4 . 
TAble 1 - Number of patients Who started orthodontic treatment ACCORding to groups 1, 2 AND 3 AND GENDERS FOR EACH YEAR

\begin{tabular}{|c|c|c|c|c|c|c|c|}
\hline Year & Gender & Up to 20 & Between 20 and 40 & Above 40 & \multicolumn{2}{|c|}{ Total } & $\%$ of adults per year $(+20$ \\
\hline \multirow[t]{2}{*}{2000} & Female & 99 & 18 & 0 & 117 & \multirow[t]{2}{*}{214} & \multirow[t]{2}{*}{12.14} \\
\hline & Male & 89 & 8 & 0 & 97 & & \\
\hline \multirow[t]{2}{*}{2001} & Female & 140 & 59 & 2 & 201 & \multirow[t]{2}{*}{320} & \multirow[t]{2}{*}{26.56} \\
\hline & Male & 95 & 23 & 1 & 119 & & \\
\hline \multirow[t]{2}{*}{2002} & Female & 152 & 78 & 2 & 232 & \multirow[t]{2}{*}{372} & \multirow[t]{2}{*}{31.18} \\
\hline & Male & 104 & 35 & 1 & 140 & & \\
\hline \multirow[t]{2}{*}{2003} & Female & 161 & 65 & 2 & 228 & \multirow[t]{2}{*}{368} & \multirow[t]{2}{*}{27.17} \\
\hline & Male & 107 & 32 & 1 & 140 & & \\
\hline \multirow[t]{2}{*}{2004} & Female & 133 & 54 & 3 & 190 & \multirow[t]{2}{*}{308} & \multirow[t]{2}{*}{25.32} \\
\hline & Male & 97 & 20 & 1 & 118 & & \\
\hline \multirow[t]{2}{*}{2005} & Female & 120 & 45 & 2 & 167 & \multirow[t]{2}{*}{290} & \multirow[t]{2}{*}{27.58} \\
\hline & Male & 90 & 33 & 0 & 123 & & \\
\hline \multirow[t]{2}{*}{2006} & Female & 96 & 44 & 4 & 144 & \multirow[t]{2}{*}{262} & \multirow[t]{2}{*}{32.44} \\
\hline & Male & 81 & 36 & 1 & 118 & & \\
\hline \multirow[t]{2}{*}{2007} & Female & 91 & 43 & 7 & 141 & \multirow[t]{2}{*}{254} & \multirow[t]{2}{*}{29.92} \\
\hline & Male & 87 & 25 & 1 & 113 & & \\
\hline \multirow[t]{2}{*}{2008} & Female & 122 & 62 & 12 & 196 & \multirow[t]{2}{*}{314} & \multirow[t]{2}{*}{34.39} \\
\hline & Male & 84 & 33 & 1 & 118 & & \\
\hline \multirow[t]{2}{*}{2009} & Female & 110 & 55 & 7 & 172 & \multirow[t]{2}{*}{304} & \multirow[t]{2}{*}{30.59} \\
\hline & Male & 101 & 30 & 1 & 132 & & \\
\hline \multirow[t]{2}{*}{2010} & Female & 97 & 35 & 2 & 134 & \multirow[t]{2}{*}{266} & \multirow[t]{2}{*}{27.81} \\
\hline & Male & 95 & 35 & 2 & 132 & & \\
\hline
\end{tabular}

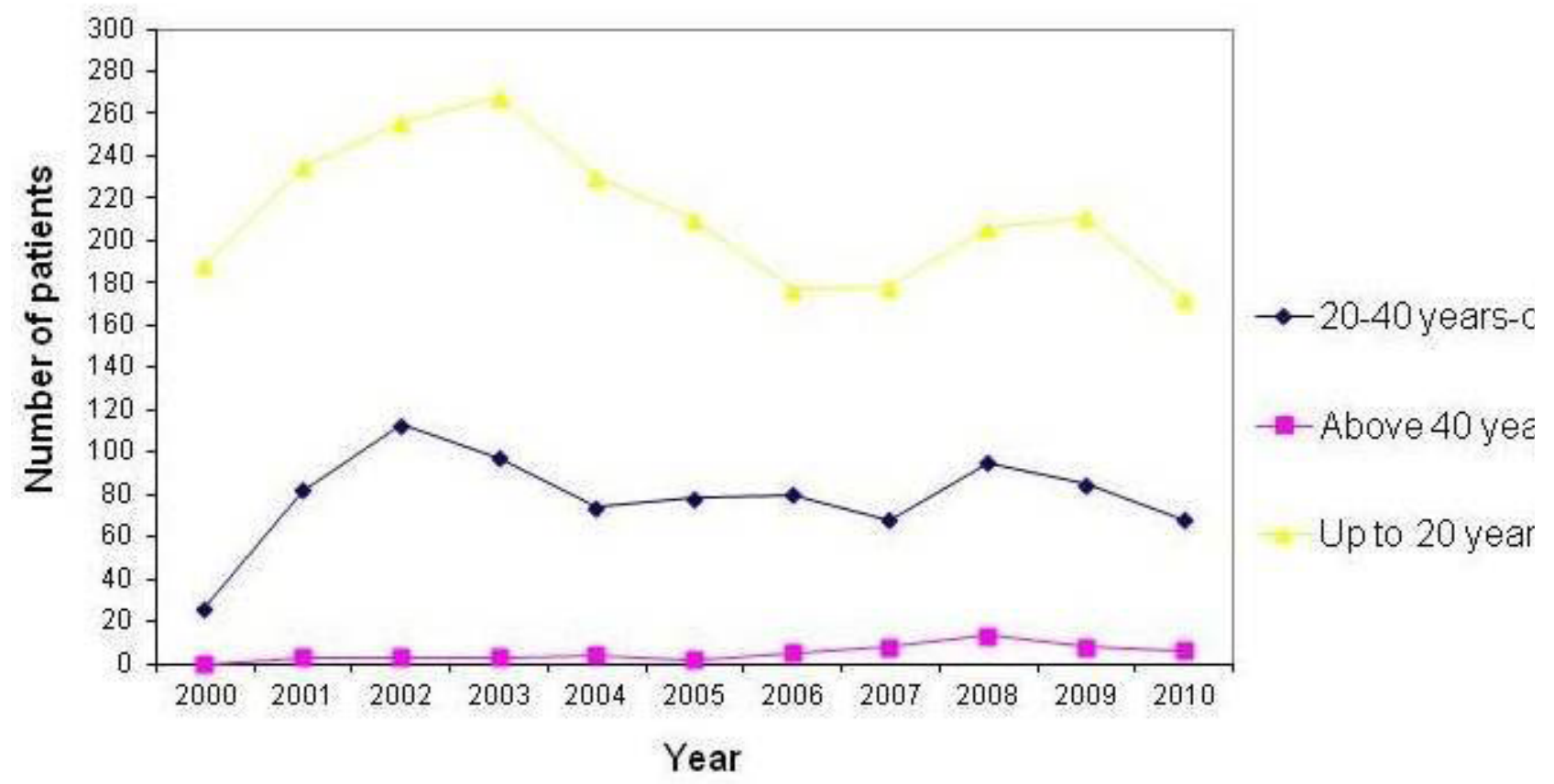

Graph 1 - Incidence of demand for orthodontic treatment in the period 2000 to 2010 according to age. 
TABLe 2 - Total PeRcentage ACCORDING to Gender AND GROUP

\begin{tabular}{c|c|c|c|c|c|c}
\hline AGE & \multicolumn{2}{|c|}{ Up to 20 years-old } & \multicolumn{2}{c}{ Between 20 and 40 years-old } & \multicolumn{2}{c}{ Above 40 years-old } \\
\hline GENDER & Total & $\%$ & Total & $\%$ & Total & $\%$ \\
\hline Female & 1321 & 68.73 & 558 & 29.03 & 43 & 2.23 \\
\hline Male & 1030 & 7.62 & 310 & 22.96 & 10 & 0.74 \\
\hline
\end{tabular}

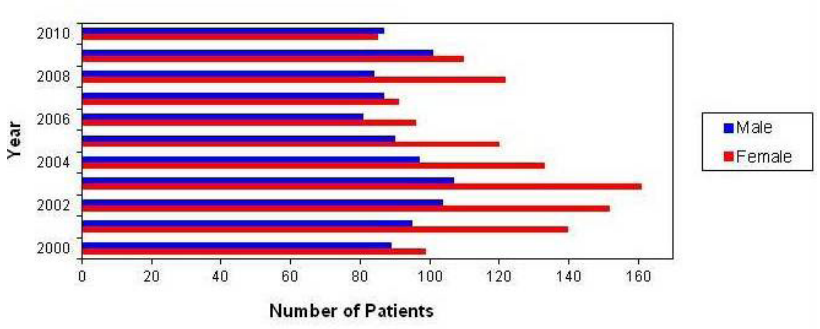

Graph 2 - Incidence of demand for orthodontic treatment according to gender in the age-range of up to 20 years-old.

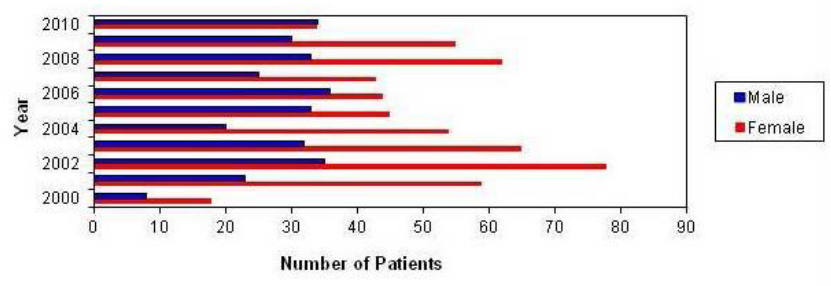

Graph 3 - Incidence of demand for orthodontic treatment according to gender in the age-range from 20 o 40 years-old.

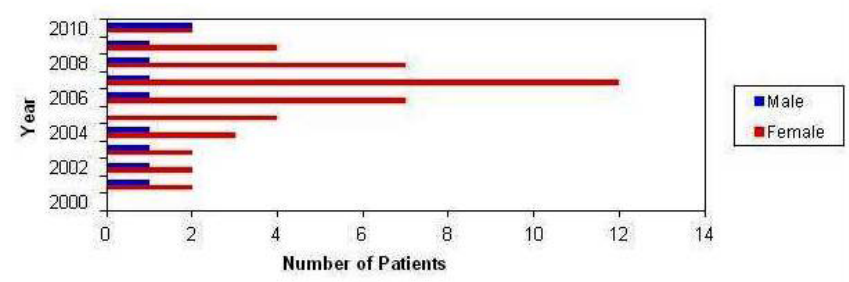

Graph 4 - Incidence of demand for orthodontic treatment according to gender in the age-range of 40 years-old.

It was observed that the number of patients who started orthodontic treatment above 40 years-old (group 3) increased from $0 \%$, in 2000 , to $4.14 \%$ in 2008 and $1.50 \%$ in 2010 . If we considered the patients of groups 2 and 3 (above 20 years-old) as adult because the growth has already finished, it was verified a percentage of $12.14 \%$ of the total of patients who started orthodontic treatment in 2000 compared with $27.81 \%$ in 2010 .

\section{Discussion}

Orthodontic treatment in adults is becoming a reality in clinical practice, mainly after the development of aesthetics and lingual appliances that minimized the anti-aesthetic effect caused by traditional metallic devices, although this latter is the most widely used because of its low cost. Adult patients usually require a multidisciplinary approach, due to periodontal problems, extensive rehabilitation, temporomandibular disorders and lack of tooth anchorage necessary for the completion of orthodontic mechanics [6].

Thus, the biomechanical principles must be adapted to the particular anatomy of the areas where tooth movement will be performed. In some cases, even with generalized tooth loss, a proper orthodontic treatment without the need of implants can be executed, simply by applying different orthodontic mechanics, overcoming the problem of lack of anchorage [19].

Another important factor in the treatment of adults is the expectation in relation to the final cosmetic result associated with an improvement of appearance, establishing or not important psychological aspects related to the improvement of social and career opportunities [2]. Thus, since the beginning of treatment, patients should be informed about the possible limitations of treatment to avoid future frustrations [6].

Prevalence studies of normal occlusion showed that $7 \%$ of Caucasian Brazilian adult population with a harmonic facial profile and who had never been orthodontically treated, present normal occlusion while 93\% present malocclusion (48\% Class I malocclusion, 36\% Class II/1, 6\% Class II/2 and $3 \%$ Class III) [30].

Considering the aforementioned discussion, we conducted this research at the Institute of Teaching and Research of Cruzeiro, in Cruzeiro, São Paulo, Brazil to evaluate the number of orthodontic treatment started in different ages (groups 1,2 and 3 ) in the period from 2000 to 2010 . It was found that most of the patients still comprised young patients up to 20 years-old (group 1: 71.85\%), which is in agreement with most of the literature studies $[2,6]$. However, the number of adult patients between 20 and 40 years-old constitutes a considerable share of $26.52 \%$. Above 40 years-old, $1.61 \%$ patients sought for orthodontic treatment. 
Some studies [2] reported that in 1970, just 5\% of the patients aged more than 18 years-old. In 1990, this number increased to $25 \%$ and it seems that the current tendency is an increasing in the number of patients above 40 years-old.

Other researches in the begging of the 90's also showed that the percentage of adult patients searching for treatment was $30 \%$ which was estimated to increase by the end of the decade due to the use of preventive measures allowing patients to reach adulthood with a greater number of teeth in the mouth [4]. In this present study, if we consider as adult, patients older than 20 years-old, groups 2 and 3 can be analyzed together, resulting in a mean of $28.14 \%$ of adult patients who started orthodontic treatment in the studied period, which is in agreement with most of the studies [2,4].

Moreover, it could also be noted that among these $28.14 \%$ of adult patients (above 20 years-old), $65.25 \%$ were female while $34.74 \%$ were male, confirming the observation of some authors [31] who have reported a higher motivation of women to undergo orthodontic treatment. According to the literature, $71.6 \%$ of adult patients undergoing orthodontic treatment are women due to the fact that this gender is more aware of their malocclusion [32] and more demanding with their appearance, appearing mostly in the samples of the studies [33].

Evidence suggests that alveolar bone reacts differently in adults compared to adolescents $[2,6]$. Adult patients in the absence of compromising dental conditions are not more prone to lose support than adolescents, but they must be evaluated carefully before starting treatment $[3,17]$. It is known that tooth movement does not promote significant loss of insertion, but this fact can be accelerated when any active periodontal disease is present, emphasizing the importance of a multidisciplinary approach throughout the orthodontic treatment, with periodontal evaluation before and during the entire orthodontic therapy $[17,19,29]$.

Other important precautions include the use of forces of low magnitude [2,19], bonding instead of banding accessories whenever possible, especially in those patients with no periodontal involvement [2], as well as an efficient anchorage system. With these precautions, it is expect to obtain an effective tooth movement, without further damage being caused to the supported tissues and roots of the elements involved [19].

Thus, patients with controlled periodontal problems and absence of multiple teeth are likely to be orthodontically treated but a multidisciplinary team has to be involved, considering the particularities of each case. Prior to orthodontic treatment, it is very important to establish an excellent oral health with controlling of periodontal disorders [19].

\section{Conclusion}

Based on these results, it can be concluded that there was a considerable increasing in the number of adult patients who started orthodontic treatment in the period from 2000 to 2010 (mean of $28.14 \%$ ). The percentage of females $(31.26 \%)$ was higher than males $(23.7 \%)$, showing that dental aesthetics is a factor of great importance for the insertion of the subject in the society.

\begin{abstract}
Resumo
A utilização de medida preventivas em odontologia e modernização dos aparelhos ortodônticos levaram os pacientes adultos a procurar o tratamento ortodôntico para melhorar sua aparência e aceitação social, além de função e saúde oral. Estes pacientes apresentam algumas particularidades como doença periodontal e perdas dentárias que dificultam a mecanoterapia, necessitando de equipe multidisciplinar, além de mecânicas mais complexas. Diante deste fato, o objetivo deste trabalho foi verificar comparativamente a proporção de pacientes adultos e jovens que iniciaram o tratamento ortodôntico no período de 2000 a 2010 e correlacionar os valores aos gêneros masculino e feminino, e a porcentagem total de pacientes que iniciaram o tratamento ortodôntico. A amostra de 3272 indivíduos foi dividida em 3 grupos, de acordo com a idade, em até os 20 (grupo 1), de 20 a 40 (grupo 2) e acima de 40 anos (grupo 3) e de acordo com o gênero. Verificouse que o número de pacientes adultos entre 20 e 40 anos representa uma considerável fatia de $26,52 \%$ e, ainda, $1,61 \%$ acima de 40 anos. Se considerarmos o paciente adulto como aquele acima de 20 anos, houve um aumento considerável de $12,14 \%$, em 2000, para 27,81\% em 2010 que iniciaram o tratamento ortodôntico, destacando-se o gênero feminino $(31,26 \%)$, principalmente nos grupos 2 e 3, demonstrando que a estética dental é um fator de crescente importância para a inserção do indivíduo na sociedade.
\end{abstract}

\title{
Palavras-chave
}

Ortodontia corretiva; estética dentária; coleta de dados. 


\section{REFERENCES}

1. Khahl-Nieke B. Retention and stability considerations for adult patients. Dent Clin North Am. 1996;40(4):961-94.

2. Proffit WR, Fields Jr HW, Sarver DM. Ortodontia contemporânea. Rio de Janeiro: Elsevier; 2007.

3. Khan M, Fida M. Assessment of psychosocial impact of dental aesthetics. J Coll Physicians Surg Pak. 2008;18(9):55964.

4. Dias PF, Gleiser R. Orthodontic treatment need in a group of 9-12-year old Brazilian school children. Braz Oral Res, 2009;23(2):182-9.

5. Klyak HA. Does orthodontic treatment affect patients quality of life?. J Dent Educ. 2008;72(8):886-94.

6. Natrass C, Sandy JR. Adult orthodontics - a review. Br J Orthod. 1995;22(4):331-7.

7. Adeyemi AT, Aderiokun GA, Denloye OO. Socio-economic status and utilization of orthodontic services in a Nigerian hospital. Odontostomatol Trop. 2008;31(122):27-33.

8. Klages U, Bruckner A, Zentner A. Dental aesthetics, selfawareness, and oral health-related quality of life in young patients. Eur J Orthod. 2004; 26 (5):507-14.

9. Johal A, Ide M. Orthodontic in the adult patient, with special reference to the periodontally compromised patient. Dent Update. 1999;26(3):101-4,106-8.

10. Svedströn-Oristo AL, Pietilä T, Pietilä I, Vahlberg T, Alanen $P$, Varrela J. Acceptability of dental appearance in a group of finished 16-t-25-year-old. Angle Orthod. 2009;79(3):479-83.

11. Capelozza Filho L. Tratamento ortodôntico em adultos: uma abordagem direcionada. Rev Dental Press Ortodon Ortop Facial. 2001;6(5):63-80.

12. Josefsson E, Lindsten R, Hallberg LR. A qualitative study of the influence of poor dental aesthetics on the lives of young adults. Acta Odontol Scand. 2010;68(1):19-26.

13. Lilja-Karlander E, Kurol J, Josefson E. Attitudes and satisfaction with dental appearance in young adults with and without malocclusion. Swed Dent J. 2003;27 (3):143-50.

14. Ngom PI, Brown R, Diagne F, Normand F, Richmond S. A cultural comparison of treatment need. Eur J Orthod. 2005;27(6):597-600.

15. Rosa RS, Oliveira PA, Faot F, Cury AADB, Garcia RCR. Prevalência de sinais e sintomas de desordens temporamandibulares e suas associações em jovens universitários. RGO. 2008;56(2):121-6.

16. Silva Filho OG. Tratamento ortodôntico em adultos - relato de caso clínico. Rev Soc Bras Ortodontia. Rio de Janeiro. 1996;3(1):25-30.

17. Boyd, R, Leggott PJ, Quinn RS, Eakle WS, Chambers D. Periodontal implications of orthodontic treatment in adults with reduced or normal periodontal tissues versus those of adolescents. Am J Orthod Dentofac Orthop. 1989;96(3):1918.

18. Hassan AH, Amin Hel-S. Association of orthodontic treatment needs and oral health-related quality of life in young patients. Am J Orthod Dentofac Orthop. 2010;137(1): 42-7.

19. Calheiros A, Fernandes A, Quintão CA, Souza EV. Movimentação ortodôntica em dentes com comprometimento periodontal: relato de um caso clínico. R Dental Press Ortodon Ortop Facial. 2005; 10(2): 111-118.

20. Pithon MM, Bernardes LAA. Tratamento Ortodôntico em Pacientes Adultos com Perdas Dentárias e Doença Periodontal: relato de caso. J Bras Ortodon Ortop Facial. 2005;10(56):142-7.
21. Paige SF. A lingual light-wire technique. J Clin Orthod. 1982;16(8):534-44.

22. Pias AC, Ambrosio AR. Movimento ortodôntico intrusivo para reduzir defeitos infra-ósseos em pacientes periodontais. RGO. 2008;56(2):188-91.

23. Ren Y, Boxum C, Sandham A. Patient's perceptions, treatment need, and complexity of orthodontic re-treatment. Eur J Orthod, 2009;31(2):189-95.

24. Tiberio D - Odontogeriatria e a ortodontia. In: Tiberior S Ortodontia Clinica contemporânea e multidisciplinar. São Paulo: Ed. Santos;2010.

25. Macedo A. Aparelhos ortodônticos estéticos em pacientes adultos.In: Cotrim-Ferreira FA, Domingos VBTC. Nova visão em Ortodontia e Ortopedia Facial dos Maxilares. In: Macedo A. São Paulo: Santos; 2010.Cap 39.p.307.

26. Tibério S. Ortodontia para adulto: a terapia do futuro. In: Cotrim-Ferreira FA, Domingos VBTC. Nova visão em Ortodontia e Ortopedia Facial dos Maxilares. São Paulo: Santos; 2010.Cap.28.p.231.

27. Suguino R. Ortodontia em adultos no século XXI - estamos preparados?. Rev Clin Ortodon Dental Press, 2006;5(4):3.

28. Eva J, Bjerklin K, Lindsten R. Self-perceived orthodontic treatment need and prevalence of malocclusion in 18 and 19 year olds in Sweden with diferent geographic origin. Sweed Dent J. 2010,34(2):95-106.

29. Rocha DS, Oliveira RSMF, Fraga MR, Vitral, RWF. Considerações no tratamento ortodôntico de pacientes adultos com comprometimento periodontal. Pesq Bras Odontoped Clin Integr. 2005;5(2):185-190.

30. Reis SAB, Capelozza Filho L, Mandetta S. Prevalência de oclusão normal e má oclusão em brasileiros, adultos, leucodermas, caracterizados pela normalidade do perfil facial. Rev Dent Press Ortodon Ortop Facial. 2002;7(5):17-25.

31. Sergl GH, Zentner A. Study of psychosocial aspects of adult orthodontic treatment. Int $\mathrm{J}$ Adult Orthodon Orthognath Surg. 1997;12(1):17-22.

32. Khan RS, Horrocks EN. A study of adult orthodontic patients and their treatment. Br J Orthod. 1991;18(3):183-94.

33. Klages U, Bruckner A, Zenter A. Dental aesthetics selfawareness and oral health-related quality of life in young adults. Eur J Orthod. 2004;26(5):507-14.

Received: 28/10/2011 Accepted: 11/05/2012

Corresponding author:

Eduardo César Werneck Av. Nesralla Rubez, 1324. Vila Canevari - Cep: 12 710-070 Cruzeiro-SP drwerneck@uol.com.br 